\title{
Histochemical map of the ectopic expression of the Arabidopsis atExt1 extensin gene in transgenic tobacco
}

\author{
G. Merkouropoulos ${ }^{1,2}$ and A.H. Shirsat ${ }^{1}$ \\ ${ }^{1}$ School of Biological Sciences, University of Wales, Bangor, \\ Gwynedd, United Kingdom \\ 2Institute of Agrobiotechnology, \\ Centre for Research and Technology Hellas, Thessaloniki, Greece \\ Corresponding author: G. Merkouropoulos / A.H. Shirsat \\ E-mail: georgios.merkouropoulos@gmail.com / a.h.shirsat@bangor.ac.uk
}

Genet. Mol. Res. 11 (3): 1830-1840 (2012)

Received May 9, 2011

Accepted January 16, 2012

Published July 19, 2012

DOI http://dx.doi.org/10.4238/2012.July.19.3

\begin{abstract}
Histochemical analysis of transgenic tobacco plants harboring the promoter of the Arabidopsis extensin gene atExt1 fused to the $\beta$-glucuronidase gene coding sequence demonstrated expression of the transgene in stem tissues. The transgene was expressed in cells of the internal and external phloem at the nodal and internodal regions of the older parts of mature stems. In younger parts of the same stem, expression of the transgene was slightly modified: expression was detected in the internal phloem in the internodal areas. In the nodal areas, the phloem tissue and the surrounding parenchyma were stained, demonstrating transgene expression. Expression was also seen in the phloem of the inflorescence; it was non-specific at the junctions of the flowers to the inflorescence. $\beta$-glucuronidase (reporter gene) staining was also observed in the pollen grains and at the base of the corolla.
\end{abstract}

Key words: Arabidopsis; Extensins; atExt1; Transgenic tobacco 


\section{INTRODUCTION}

Extensins are proteins that are secreted into the primary wall of plant cells (Jose and Puigdomenech, 1993; Showalter, 1993; Kieliszewski and Lamport, 1994; Cassab, 1998; Sommer-Knudsen et al., 1998; Jamet et al., 2000; Showalter et al., 2010; Lamport et al., 2011). The pentapeptide motif Ser(Pro) $)_{4}$ occurs many times throughout the primary structure of extensins and comprises their structural characteristic feature. This motif is followed by the spacer sequence, an amino acid tail, which varies in length and composition: valine, tyrosine, histidine, lysine, and threonine are commonly found in the spacer sequences of extensins.

Extensins undergo a series of post-translational modifications that greatly affect their biochemical properties. Firstly, the proline residues incorporated in the $\operatorname{Ser}(\operatorname{Pro})_{4}$ motif are hydroxylated to hydroxyproline. Hydroxyproline is an unusual amino acid, which is found only in very few proteins, including collagen in animals and hydroxyproline-rich glycoproteins (HRGPs) and arabinogalactan proteins in plants (Showalter and Varner, 1989). Secondly, the serine and hydroxyproline residues of the $\operatorname{Ser}(\mathrm{Hyp})_{4}$ motif are glycosylated with a single galactose and one to four arabinose residues, respectively. The arabinosyl side chains of the hydroxyprolines are thought to stabilize the protein in a polyproline II helical conformation (van Holst and Varner, 1984; Stafstrom and Staehelin, 1986). The pentapeptide glycosylation domains of the $\operatorname{Ser}(\mathrm{Hyp})_{4}$ motif act as short, rigid, structurally reinforced hydrophilic domains (Cooper, 1988) and has been proposed to play a critical role in the assembly of the extensin molecules in the wall and also in the interaction of extensins with other cell wall components (Cannon et al., 2008). The third post-translational modification of extensins occurs after the extensin glycopeptides are secreted into the wall, where they form a network by building intra- and inter-cross-links via tyrosine residues. The nature of these cross-links is not yet determined in detail, although it seems that they occur via the formation of isodityrosine, i.e., "an oxidatively coupled dimer of two tyrosine units linked by a diphenyl ether bridge" (Fry, 1982). In addition, another two tyrosine derivatives have been detected suggesting new potential cross-links: di-isodityrosine and pulcheroshine. Di-isodityrosine is composed of four oxidatively coupled tyrosine residues and is formed either by the direct coupling of two molecules of isodityrosine or by the sequential coupling of two tyrosine molecules to isodityrosine via an intermediate trimer, the pulcheroshine (Brady et al., 1996). It was suggested that di-isodityrosine could form either an intrapolypeptide loop, which could entrap other wall polymers (such as pectins) or an interpolypeptide cross-link. The tripeptide sequence Val-Tyr-Lys has been identified as the minimal recognition motif to manifest an intermolecular cross-linking site (Kieliszewski and Lamport, 1994; Schnabelrauch et al., 1996).

Transgenic tobacco plants expressing fusion genes with the GUS coding sequence being under the transcriptional control of various extensin gene promoters have been produced to investigate extensin gene regulation. The $n p E x t:: G U S$ and Ext $1.4:: G U S$ fusion genes, for example, were transformed into tobacco plants in order to study the expression patterns of the $n p E x t$ (Tire et al., 1994) and the Ext1.4 (Hirsinger et al., 1999) tobacco extensin genes in a homologous system. Tobacco plants have also been used as a heterologous system to study the expression pattern of extensin genes isolated from species for which an efficient transformation method is lacking. For example, the expression of the extA::GUS, HRGP4.1::GUS, and the SbHRGP3::GUS transgenes were examined into tobacco plants, elucidating the spatial and temporal regulation of the oilseed rape extensin gene extA (Shirsat et al., 1991), the bean extensin gene HRGHP4.1 
(Wycoff et al., 1995), and the soybean extensin gene SbHRGP (Ahn et al., 1996), respectively. There is no direct evidence concerning the role extensins play in the plant cell wall, although substantial indirect evidence suggests their involvement in plant development and also in defence. Lately, it has been suggested that extensins play a crucial role in the assembly of the cell wall polymers: the positively charged extensin reacts with the acidic wall polymers to create a template serving for the orderly assembly of the wall polymers (Cannon et al., 2008).

The atExt1 extensin gene is the first extensin gene that had been isolated from Arabidopsis and it has been characterised in a homologous system (Merkouropoulos et al., 1999; Merkouropoulos and Shirsat, 2003). Here, we detail the ectopic expression of the Arabidopsis extensin gene atExt1, as an atExt1::GUS gene fusion, in tobacco. This detailed analysis consisted of observing successive sections of the transgenic plants, practising our belief that expression analysis should be performed in a very thorough manner in order to detect potential differences among the various tissues. In addition, our study enables the direct comparison of the expression patterns of the various extensin gene family members in tobacco, a widely used experimental system to analyse the developmental and stress-induced expression of many extensin genes in the past (Tire et al., 1994; Wycoff et al., 1995; Ahn et al., 1996; Shirsat et al., 1991, 1996; Hirsinger et al., 1999).

\section{MATERIAL AND METHODS}

\section{Experimental plant material and growth conditions}

Tobacco plants (Nicotiana tabacum cv. Samson) were grown in a growth room where the temperature ranged between $20^{\circ}$ and $25^{\circ} \mathrm{C}$, with a 16 -h light $/ 8$-h dark cycle. The plants were grown in a 5:3 mix of compost (John Innes potting No. 1) and perlite in large plastic pots. Every three weeks they were fed with $6 \mathrm{~g} / \mathrm{L}$ phostrogen (Phostrogen Ltd., Deeside, Clwyd, UK).

\section{Construction of the atExt1::GUS gene fusion and production of transgenic tobacco plants}

The pBI101.3-based pGM5.3 clone, which contained the atExt1::GUS fusion construct (Merkouropoulos and Shirsat, 2003) was mobilised from Escherichia coli DH5 $\alpha$ cells into the Agrobacterium tumefaciens strain LBA4404 in a tri-parental mating, using the helper plasmid pRK2013. Successfully transformed A. tumefaciens strains were selected on the basis of kanamycin resistance and were used to transform tobacco leaf discs by the following method, which had been originally described by Ellis et al. (1988).

A $25-\mathrm{mL}$ culture of the A. tumefaciens strain harbouring the atExt $1:: G U S$ gene fusion was grown in LB media containing $50 \mu \mathrm{g} / \mathrm{mL}$ kanamycin sulphate, $500 \mu \mathrm{g} / \mathrm{mL}$ streptomycin sulphate and $100 \mu \mathrm{g} / \mathrm{mL}$ rifampicin, at $28^{\circ} \mathrm{C}$. The bacterial cells were collected by centrifugation at $4000 \mathrm{rpm}$ for $10 \mathrm{~min}$, washed two times in $2 \mathrm{mM} \mathrm{MgSO}_{4}$ and resuspended in $25 \mathrm{~mL}$ MS1 medium [4.71 g/L MS salts, $20 \mathrm{~g} / \mathrm{L}$ sucrose, $1 \mathrm{mg} / \mathrm{L}$ 6-benzylaminopurine (BAP), 0.1 $\mathrm{mg} / \mathrm{L}$ 6-naphthaleneacetic acid (NAA), $\mathrm{pH}$ 5.8)] on a Petri dish. Tobacco leaves at different developmental stages were surface sterilized in $70 \%$ ethanol for $30 \mathrm{~s}$, washed with distilled water and then soaked in $\mathrm{Na}(\mathrm{OCl})_{2}$ with occasional agitation for $15 \mathrm{~min}$. After being washed three times in distilled water, 4- to 6-mm diameter leaf discs were cut from the leaves using a 
sterile blade, avoiding major veins. The discs were left floating on the A.tumefaciens suspension for 10 to $60 \mathrm{~min}$. As a control, leaf pieces were left floating in sterile water. Four to five leaf discs were then transferred onto MS2 plates $(4.71 \mathrm{~g} / \mathrm{L}$ MS salts, $20 \mathrm{~g} / \mathrm{L}$ sucrose, $1 \mathrm{mg} / \mathrm{L}$ BAP, $0.1 \mathrm{mg} / \mathrm{L}$ NAA, pH 5.8, 0.8\% agar, $200 \mu \mathrm{g} / \mathrm{mL}$ augmentin, $100 \mu \mathrm{g} / \mathrm{mL}$ kanamycin sulphate), the plates were sealed and left at $20^{\circ}$ to $24^{\circ} \mathrm{C}$ with a 16 -h light $/ 8$-h dark cycle. About $48 \mathrm{~h}$ later, the leaf pieces were transferred into Magenta vessels containing $50 \mathrm{~mL}$ MS1 media supplemented with $400 \mu \mathrm{g} / \mathrm{mL}$ augmentin and gently agitated overnight before being placed on MS2 plates and cultured as before. Two weeks later, 39 calluses were visible on the periphery of the disks. About 5 weeks after the transformation event, the leaf pieces were transferred onto fresh MS2 plates to enhance the growth of the calluses. Once parts of the calluses started to differentiate into shootlets (about seven to eight weeks after the transformation event), they were transferred into Magenta pots (Magenta ${ }^{\mathrm{TM}}$, Sigma Chemical Co.) containing MS3 media (2.35 $\mathrm{g} / \mathrm{L}$ MS salts, $5 \mathrm{~g} / \mathrm{L}$ sucrose, $0.8 \%$ agar, $\mathrm{pH} 5.8,100 \mu \mathrm{g} / \mathrm{mL}$ augmentin, $100 \mu \mathrm{g} / \mathrm{mL}$ kanamycin sulphate). At this stage, parts of all 39 calluses were analysed histochemically for GUS detection. They all stained blue, although at different intensities. GUS staining was always seen on the periphery of the callus. The newly differentiated part of the callus (a primary shoot bearing small leaves) never stained blue (Figure 1A). GUS staining was never detected on calluses developed from the control-treated discs (data not shown). When rooted, the young plantlets were transferred onto MS4 plates (4.71 g/L MS salts, $10 \mathrm{~g} / \mathrm{L}$ sucrose, $0.8 \%$ agar, $\mathrm{pH} 5.8,100 \mu \mathrm{g} / \mathrm{mL}$ augmentin, $100 \mu \mathrm{g} / \mathrm{mL}$ kanamycin sulphate).

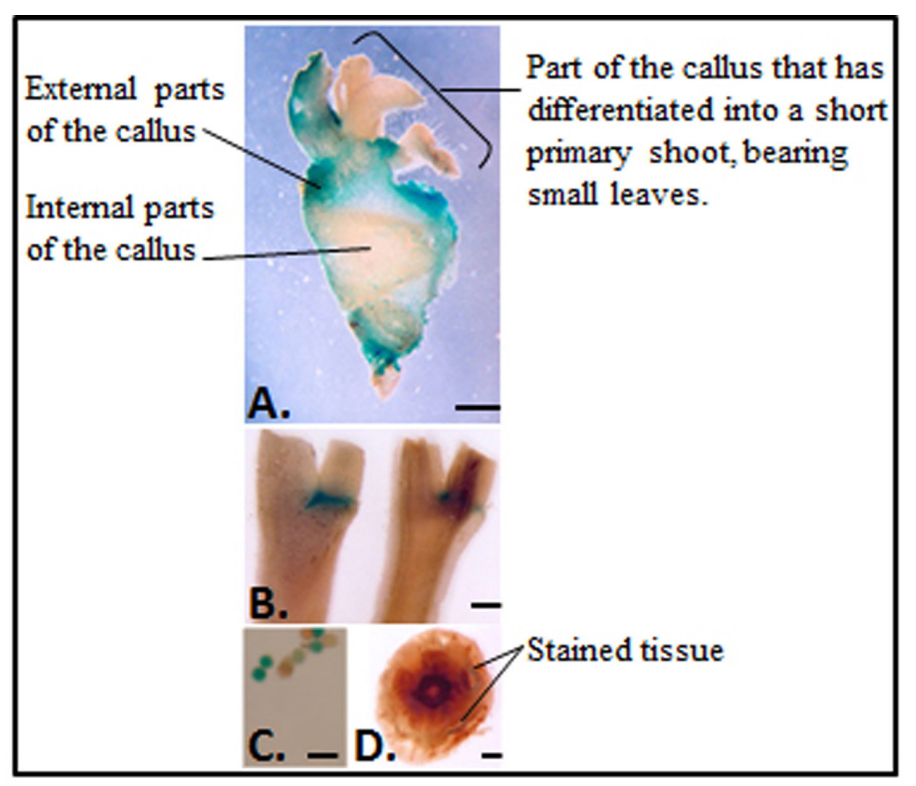

Figure 1. Histochemical localisation of atExt $1:: G U S$ fusion gene expression in various tissues of transgenic tobacco plants carrying the atExt $1::$ GUS fusion construct. A. Section of a recombinant Agrobacterium tumefaciens-induced tobacco callus at the stage of differentiation into shoot. The A. tumefaciens strain used carries the atExt $1: G U S$ fusion gene. Expression of the fusion gene is only seen on the external part of the callus. Neither the internal part of the callus nor the newly differentiated part of the callus expresses the transgene. B. Longitudinal section of the junction of the flower petiole to the daughter branch. C. Pollen grains. D. Transverse section of the base of the flower. Bar size $=1 \mathrm{~mm}$. 
After they had produced an extensive root system, they were transplanted into pots containing a sterile compost:perlite (2:1) mix. Histochemical analysis was performed on sections taken from the stem and the nodal regions of mature plants.

\section{GUS histochemical assays}

Histochemical assays were performed as described by Jefferson et al. (1987). Successive transverse hand sections taken from a variety of tissues were incubated in $50 \mathrm{mM}$ $\mathrm{NaH}_{2} \mathrm{PO}_{4}, \mathrm{pH}$ 7.0, containing $1 \mathrm{mM}$ 5-bromo-4-chloro-3-indolyl glucuronide (X-Gluc) dissolved in dimethyl formamide and $18 \mathrm{mM}$ cycloheximide, at $37^{\circ} \mathrm{C}$ overnight. The sections were fixed in $3 \%$ gluteraldehyde (prepared in $\mathrm{NaH}_{2} \mathrm{PO}_{4}, \mathrm{pH} 7.0$ ) at $4^{\circ} \mathrm{C}$ overnight, and stored in $100 \%$ ethanol. The sections were photographed on a Leica Wild M8 microscope, using Agfa Ultra 50 color film.

\section{RESULTS}

\section{Histochemical localisation of atExt1::GUS in stem tissues}

In the nodes of young and growing stems, i.e., stems that have not yet formed an inflorescence, expression of the transgene was histochemically localised in the cells of the internal and external phloem at the site where the leaf trace emerges (Figure 2B; 1-3), whereas in sections closer to the stem/petiole fork expression was expanded in the parenchyma that surrounds the leaf vascular bundle (Figure 2B; 4, 5). Occasionally, expression of the transgene was observed in internal phloem cells that were not close to the site of the emerging leaf.

In the internodal regions of mature stems, i.e., stems that have formed an inflorescence, the transgene was expressed in the cells of the internal phloem and at lower levels in the cells of the external phloem (Figure 2C, E and G). At the nodal regions of mature stems, however, the transgene was expressed in both the internal and external phloem tissues, with the expression being heavier in the areas that surround the vascular bundle of the leaf trace (Figure 2D, F and $\mathrm{H}$ ). Expression of the transgene was occasionally seen in the parenchyma that surrounds the leaf vascular bundle and coincided with weak expression in the cells of the external phloem (Figure 2H; 3). This pattern was altered in the young regions of the mature stem (close to the inflorescence), where expression of the transgene was weak at the external phloem of the leaf trace and coincided with expression in the parenchyma cells at the base of the growing leaf (Figure 2I and J). GUS staining is also shown in the longitudinal sections in Figure 1.

\section{Expression pattern of the atExt1::GUS in inflorescence, flowers and pollen tubes}

At the nodes of the older parts of the inflorescence, the transgene was expressed specifically in the cells of the internal phloem (Figure 3B). At younger nodes, however, expression of the transgene was seen in the internal phloem and also in the parenchyma (Figure 3G). Similarly, the transgene was expressed in the internal phloem and the parenchyma at the flower petiole/inflorescence stem junction (Figure $3 \mathrm{H}$, I and J). GUS staining was also observed in the pollen grains (Figure 1C) and at the base of the corolla (Figure 1D). 


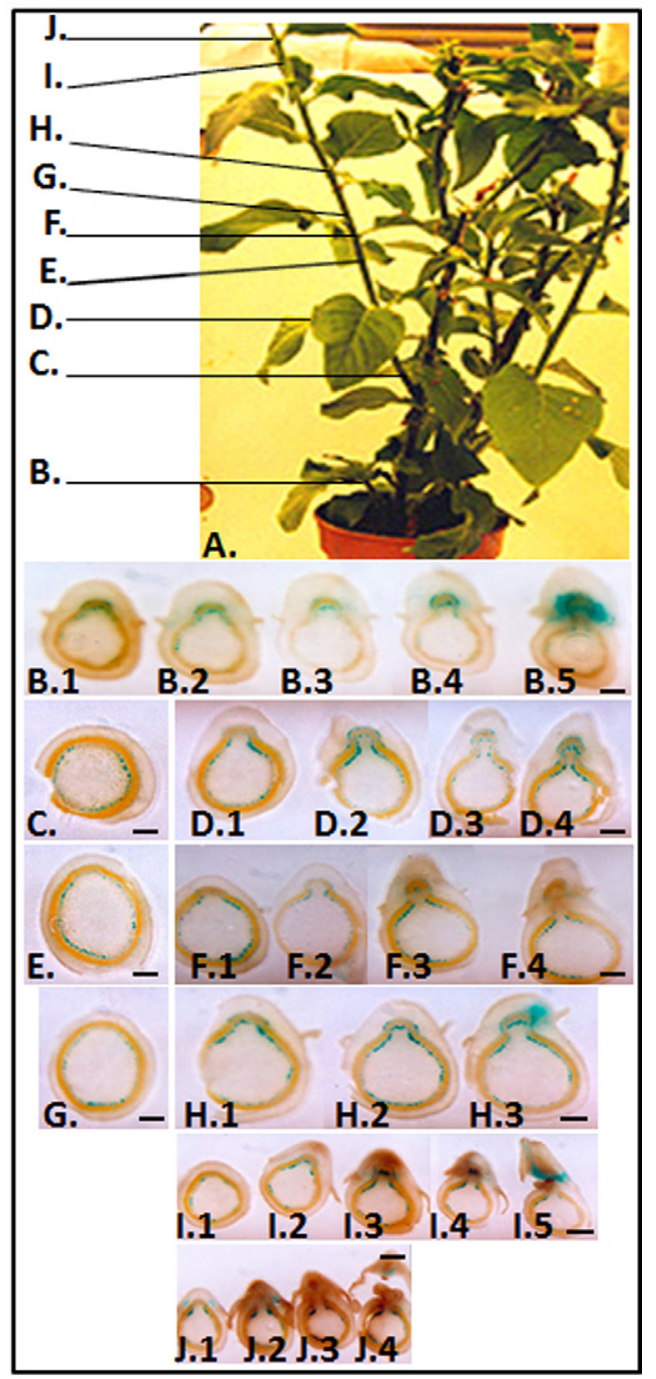

Figure 2. Histochemical localisation of the atExt $1:: G U S$ fusion gene expression in the stem of transgenic tobacco plants carrying the atExt $1:: G U S$ fusion construct. A. Image of the plant and location of the sites where the sections were obtained. All sections (apart those shown in B) were taken from a well-grown branch of the plant, called "the stem". The stem at the moment of sampling possessed 17 leaves and a well-formed inflorescence. B-J) Series of sections: numbering in all cases starts from the older parts and proceeds to the younger ones. B. A series of five sections were taken from a young and growing stem at the base of the plant. C. A section was taken from the internode between the 1st (older) and the 2 nd leaf of the stem. D. A series of four sections was taken from the node of the 2 nd leaf of the stem. E. A section was taken from the internode between the 2nd and 3rd leaf of the stem. F. A series of four sections was taken from the node of the 4 th leaf of the stem. G. A section was taken between the 5th and the 6 th leaf of the stem. H. A series of three sections was taken from the node of the 7 th leaf of the stem. I. A series of five sections was taken from the node of the 13th leaf of the stem. The first section of this series is from the internode between the 12th and 13th leaves. J. A series of sections was taken from the node of the 15 th leaf of the stem. The first section of this series is from the internode between the 14th and 15th leaves. In all series of sections, the sections were taken successively from underneath the node (left) to the node (right). Bar size $=0.6 \mathrm{~mm}$. 


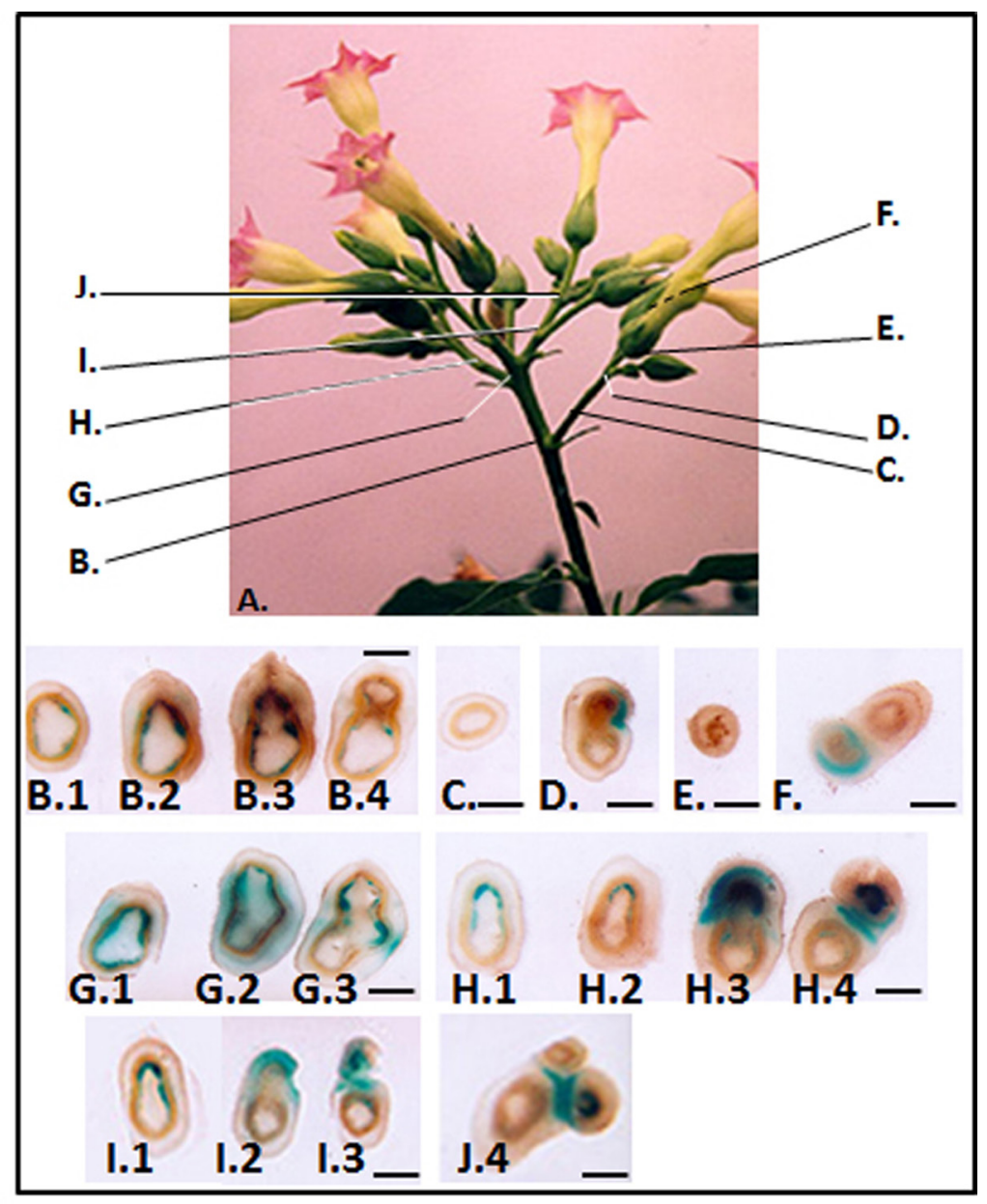

Figure 3. Histochemical localisation of atExt $1:: G U S$ fusion gene expression in the inflorescence of transgenic tobacco carrying the atExt $1:: G U S$ fusion construct. A. Image of the inflorescence and the sites where the sections were obtained. B. A series of four sections was obtained from the junction of the inflorescence to the stem. C. A section was obtained from the daughter branch (between the receptacle and the stem). D. A section was obtained from the junction of the flower petiole to the daughter branch. E. A section was obtained from the flower petiole of an opened flower (between the daughter branch and the receptacle). F. A section was obtained from the flower petiole of a closed flower. G. A series of three sections was obtained from the junction of three daughter stems. $\mathbf{H}$. A series of four sections was obtained from the junction of the flower petiole to the daughter branch. I. A series of three sections was obtained from the junction of the flower petiole to the daughter branch. $\mathbf{J}$. A section was obtained from the junction of three flower petioles. In all series of sections, the sections were taken successively from underneath the junction (left) to the junction (right). Bar size $=1 \mathrm{~mm}$.

\section{DISCUSSION}

Regulation of various extensin genes from dicotyledonous plants has been studied in transgenic tobacco species by histochemical localisation of their promoter driven GUS expres- 
sion. Studying the expression of the HRGP4.1::GUS fusion gene in transgenic tobacco plants, Wycoff et al. (1995) observed GUS staining in all the stem nodal tissues with the highest GUS activity seen in the vascular tissue and the pith. No staining was detected in the tissues of the internodal regions. Similar findings had also been reported by Shirsat et al. (1996) who detected expression of the extA::GUS fusion gene in the internal and external phloem and in the cortical parenchyma in transgenic tobacco at the regions where the auxiliary stalk was developed. In another study, GUS staining localised expression of the tobacco Ext1.4::GUS fusion gene to the internal and external phloem at stem nodes and also in the floral pedicels (Hirsinger et al., 1999; Salvá and Jamet, 2001). Although these studies show that activation of extensin promoters is limited mainly to the vascular tissue of the stem nodal areas, they do not provide adequate information on either the exact location or the age of the tissues analysed. A more detailed description of the age and location of the tissues analysed has been reported by Tire et al. (1994). Using in situ hybridisation, they found that the $n p E x t$ tobacco extensin gene was expressed in an age-dependent manner: in mature regions of the stem the gene was expressed in the cortical cells surrounding the developing vascular bundle of the leaf trace, while in young stem nodes expression was limited only to the cortical cells around the leaf trace.

In the present study, an extensive analysis of the atExt $1:: G U S$ fusion gene expression patterns in a heterologous system, transgenic tobacco, is described with considerable emphasis on determining the age and location of the tissues studied. Observing the location of GUS staining, expression of the transgene in the young internodal tissues of mature stem was found to be limited to the internal phloem, whilst towards the nodal regions expression became non-specific, staining the parenchyma around the leaf trace. In the old parts of the same stem, GUS staining was found in the internal and external phloem: judging from the intensity of the staining, expression of the fusion gene was higher towards the nodes where the vascular bundle of the growing leaf was formed. An intermediate pattern of expression was observed between the young and the old stem tissues with staining to be lower in the external phloem and higher in the internal phloem. This pattern of expression is slightly modified in inflorescence tissues. Expression of the transgene is seen in the internal phloem, whilst it becomes non-specific, staining the parenchyma at the junctions of the flower stalk to the inflorescence. Expression of the transgene was never detected in the region between two junctions. These expression patterns are remarkably similar to the expression patterns reported in the past for extensin gene promoter-GUS fusions in tobacco stem tissues. Taken all together, they show that extensin genes in tobacco plants are expressed mainly in the stem nodal vascular tissues, supporting the idea that extensin gene expression is cell type specific rather than uniform to all cells (Jamet et al., 2000).

As the extensin gene promoter::GUS fusion genes transformed into tobacco plants (in both homologous and heterologous systems) display similar expression patterns in stem tissues, it is reasonable to assume that these promoter regions contain the necessary cis-acting elements that interact with the tobacco transcription machinery. Elliott and Shirsat (1998) identified the negative regulator region (NRR) in the extA oilseed rape extensin gene promoter as the region where nuclear proteins bind resulting in repression of the transgene. It was suggested that disassociation of this transcription factor results in widespread expression of the transgene in all tissues. Since widespread expression was observed in the nodal regions, which are under tensile stress, it was hypothesized that repression was overcome by tensile stress (Elliott and Shirsat, 1998). If this is the case, then cis-acting elements present in the extA gene 
promoter NRR would have been expected to be present in the atExt1 gene promoter because the expression of the atExt $1:: G U S$ fusion gene in transgenic tobacco is almost identical to that of extA::GUS in transgenic tobacco. Elliott (1998) performed an examination of the NRR of the extA gene promoter sequence in order to identify sequences with similarity to known transcription factor binding sites. This examination resulted in the location of four sites, which were highly identical to the Enhancer element (Enh), Lectin element (Lec), and VSF element transcription factor binding sites (Table 1). Motifs almost identical to those identified in the NRR of the extA gene promoter sequence were also found in the atExt1 gene promoter sequence (Table 1). This implies the occurrence of a similar regulatory system, which controls expression of extensin genes in oilseed rape and Arabidopsis.

\begin{tabular}{|c|c|c|c|c|}
\hline Putative transcription factor & $\begin{array}{l}\text { Putative } c i s \text {-acting } \\
\text { elements in the NRR of } \\
\text { the ext } A \text { gene promoter }\end{array}$ & $\begin{array}{l}\text { Location in the } \\
\text { NRR of the ext } A \\
\text { gene promoter }\end{array}$ & $\begin{array}{l}\text { Putative } c i s \text {-acting } \\
\text { in the NRR of the } \\
\text { atExtl gene promoter }\end{array}$ & $\begin{array}{l}\text { Location in the } \\
\text { NRR of the atExtl } \\
\text { gene promoter }\end{array}$ \\
\hline $\begin{array}{l}\text { Enhancer (Enh) element: ATTTGCAT } \\
\text { (Kawaoka et al., 1992) }\end{array}$ & $\begin{array}{l}\text { ATTCGCAT } \\
\text { TTTTGCAT }\end{array}$ & $\begin{array}{l}-650 \text { to }-643, \\
-472 \text { to }-466\end{array}$ & GTTTCGCAT & -1923 to -1915 \\
\hline $\begin{array}{l}\text { Lectin element (Lec): ATT(A/T)AAT } \\
\text { (Jofuku et al., 1987) }\end{array}$ & TTAAGTTATTAATTA & -603 to -589 & TTAAGTTGTTG & -1519 to -1505 \\
\hline $\begin{array}{l}\text { VSF: GTGG } \\
\text { (Torres-Schumann et al., 1996) }\end{array}$ & AATATAGTGGATT & -477 to -474 & $\begin{array}{l}\text { ATGAGTGTGGAGG } \\
\text { AATTTAGTGGGAA } \\
\text { TATTTTGTGATT }\end{array}$ & $\begin{array}{l}-2924 \text { to }-2921 \\
-692 \text { to }-689 \\
-661 \text { to }-658\end{array}$ \\
\hline
\end{tabular}

The exact locations of these factors on the extA and the atExt1 gene promoters are shown. Numbering in the extA gene promoter is relative to the transcription start point, while in the atExt1 gene promoter, numbering is relative to the translation start site (the adenine of the initiator methionine was numbered as +1 and sequences upstream of $\mathrm{A}_{+1}$ are indicated with the minus (-) symbol). All motifs are in the 5'- to 3'-direction. Where a core motif of the transcription factor binding sites has been described, it is underlined. References are given underneath the name of the respective transcription factor binding site (in parentheses).

Expression of the atExt1 gene was detected in the pollen grains of transgenic tobacco plants carrying the atExt $1:: G U S$ fusion gene (most but not all pollen grains were stained blue). To our knowledge, the only study where an extensin gene was reported to be expressed in the pollen grains was the Ext1.4 tobacco extensin gene in tobacco plants harbouring the Ext1.4::GUS fusion gene (Hirsinger et al., 1999). Expression of this transgene was detected in pollen grains before and after pollen grain germination, leading to the suggestion that the Ext1.4 gene was involved in pollen maturation and pollen tube formation (Hirsinger et al., 1999).

GUS synthesis has not been seen in pollen grains from $\mathrm{T}_{1}$ transgenic Arabidopsis plants carrying the atExt $1:: G U S$ fusion gene. However, expression of the atExt $1:$ GUS fusion construct was detected in the stigma during pollination suggesting that extensin expression is involved in the reproductive processes; their exact role is, however, not yet clear. Similarly, the atExt $1:: G U S$ fusion gene is expressed at the base of the corolla, which is again of unknown function, therefore providing a topic for further study.

\section{ACKNOWLEDGMENTS}

G. Merkouropoulos was supported by the State Scholarships Foundation of Greece. We would like to thank Dr. Kaf Elliott, Dr. Nik Sidik and Wendy Grail for their invaluable laboratory help and enthusiasm. 


\section{REFERENCES}

Ahn JH, Choi Y, Kwon YM, Kim SG, et al. (1996). A novel extensin gene encoding a hydroxyproline-rich glycoprotein requires sucrose for its wound-inducible expression in transgenic plants. Plant Cell 8: 1477-1490.

Brady JD, Sadler IH and Fry SC (1996). Di-isodityrosine, a novel tetrameric derivative of tyrosine in plant cell wall proteins: a new potential cross-link. Biochem J. 315: 323-327.

Cannon MC, Terneus K, Hall Q, Tan L, et al. (2008). Self-assembly of the plant cell wall requires an extensin scaffold. Proc. Natl. Acad. Sci. U. S. A. 105: 2226-2231.

Cassab GI (1998). Plant cell wall proteins. Annu. Rev. Plant Physiol. Plant Mol. Biol. 49: 281-309.

Cooper JB (1988). Cell Wall Extension Genes. In: Temporal and Spatial Regulation of Plant Genes (Verma DPS and Goldberg RB, eds.). Springer Verlag GmbH, Berlin, 235-251.

Elliott KA (1998). The Regulation of extA: An Extensin Gene from Brassica napus. PhD Thesis. University of Wales, Bangor.

Elliott KA and Shirsat AH (1998). Promoter regions of the extA extensin gene from Brassica napus control activation in response to wounding and tensile stress. Plant Mol. Biol. 37: 675-687.

Ellis JR, Shirsat AH, Hepher A, Yarwood JN, et al. (1988). Tissue-specific expression of a pea legumin gene in seeds of Nicotiana plumbaginifolia. Plant Mol. Biol. 10: 203-214.

Fry SC (1982). Isodityrosine, a new cross-linking amino acid from plant cell-wall glycoprotein. Biochem. J. 204: 449-455.

Hirsinger C, Salva I, Marbach J, Durr A, et al. (1999). The tobacco extensin gene Ext 1.4 is expressed in cells submitted to mechanical constraints and in cells proliferating under hormone control. J. Exp. Bot. 50: 343-355.

Jamet E, Guzzardi P and Salva I (2000). What do transgenic plants tell us about the regulation and function of cell-wall structural proteins like extensins? Russ. J. Plant Physiol. 47: 318-326.

Jefferson RA, Kavanagh TA and Bevan MW (1987). GUS fusions: beta-glucuronidase as a sensitive and versatile gene fusion marker in higher plants. EMBO J. 6: 3901-3907.

Jofuku KD, Okamuro JK and Goldberg RB (1987). Interaction of an embryo DNA binding protein with a soybean lectin gene upstream region. Nature 328: 734-737.

Jose M and Puigdomenech P (1993). Structure and expression of genes-coding for structural proteins of the plant cell wall. New Phytol. 125: 259-282.

Kawaoka A, Sato S, Nakahara K, Matsushima N, et al. (1992). Expression and promoter activity of genes for isozymes of horsheradish peroxidase. Plant Cell Physiol. 33: 1143-1150.

Kieliszewski MJ and Lamport DT (1994). Extensin: repetitive motifs, functional sites, post-translational codes, and phylogeny. Plant J. 5: 157-172.

Lamport DT, Kieliszewski MJ, Chen Y and Cannon MC (2011). Role of the extensin superfamily in primary cell wall architecture. Plant Physiol. 156: 11-19.

Merkouropoulos G and Shirsat AH (2003). The unusual Arabidopsis extensin gene atExt1 is expressed throughout plant development and is induced by a variety of biotic and abiotic stresses. Planta 217: 356-366.

Merkouropoulos G, Barnett DC and Shirsat AH (1999). The Arabidopsis extensin gene is developmentally regulated, is induced by wounding, methyl jasmonate, abscisic and salicylic acid, and codes for a protein with unusual motifs. Planta 208: 212-219.

Salvá I and Jamet E (2001). Expression of the tobacco Ext 1.4 extensin gene upon mechanical constraint and localization of regulatory regions. Plant Biol. 3: 32-41.

Schnabelrauch LS, Kieliszewski M, Upham BL, Alizedeh H, et al. (1996). Isolation of pl 4.6 extensin peroxidase from tomato cell suspension cultures and identification of Val-Tyr-Lys as putative intermolecular cross-link site. Plant $J$. 9: 477-489.

Shirsat AH, Wilford N, Evans IM, Gatehouse LN, et al. (1991). Expression of a Brassica napus extensin gene in the vascular system of transgenic tobacco and rape plants. Plant Mol. Biol. 17: 701-709.

Shirsat AH, Wieczorek D and Kozbial P (1996). A gene for Brassica napus extensin is differentially expressed on wounding. Plant Mol. Biol. 30: 1291-1300.

Showalter AM (1993). Structure and function of plant cell wall proteins. Plant Cell 5: 9-23.

Showalter AM and Varner JE (1989). Plant Hydroxyproline-rich Glycoproteins. In: The Biochemistry of Plants: A Comprehensive Treatise. (Marcus A, ed.). Academic Press Inc., New York, vol. 15, 485-520.

Showalter AM, Keppler B, Lichtenberg J, Gu D, et al. (2010). A bioinformatics approach to the identification, classification, and analysis of hydroxyproline-rich glycoproteins. Plant Physiol. 153: 485-513.

Sommer-Knudsen J, Bacic A and Clarke AE (1998). Hydroxyproline-rich plant glycoproteins. Phytochemistry 47: $483-$

Genetics and Molecular Research 11 (3): 1830-1840 (2012) CFUNPEC-RP www.funpecrp.com.br 
497.

Stafstrom JP and Staehelin LA (1986). The role of carbohydrate in maintaining extensin in an extended conformation. Plant Physiol. 81: 242-246.

Tire C, De Rycke R, De Loose M, Inze D, et al. (1994). Extensin gene expression is induced by mechanical stimuli leading to local cell wall strengthening in Nicotiana plumbaginifolia. Planta 195: 175-181.

Torres-Schumann S, Ringli C, Heierli D, Amrhein N, et al. (1996). In vitro binding of the tomato bZIP transcriptional activator VSF-1 to a regulatory element that controls xylem-specific gene expression. Plant J. 9: 283-296.

van Holst GJ and Varner JE (1984). Reinforced Polyproline II Conformation in a Hydroxyproline-Rich Cell Wall Glycoprotein from Carrot Root. Plant Physiol. 74: 247-251.

Wycoff KL, Powell PA, Gonzales RA, Corbin DR, et al. (1995). Stress activation of a bean hydroxyproline-rich glycoprotein promoter is superimposed on a pattern of tissue-specific developmental expression. Plant Physiol. 109: $41-52$. 